\title{
Selenium and Vitamin E Supplementation on Blood Antioxidants in Moderately Exercised Horse
}

\author{
Elías Velázquez Cantón and Aurora H Ramírez Pérez* \\ Facultad de MedicinaVeterinaria y Zootecnia. UNAM. Ciudad de México, Mexico
}

Submission: September 01, 2018; Published: September 11, 2018

*Corresponding author: Aurora HRamírezPérez, Animal Nutrition and Biochemistry Department. Facultad de MedicinaVeterinaria y Zootecnia, Universidad Nacional Autónoma de México. UNAM-CU, 04510, Mexico, Email: rpereza@unam.mx

\begin{abstract}
The objective of this article is to discuss the effect of selenium and vitamin E supplementation on the activity of erythrocyte superoxide dismutase and zinc $(\mathrm{Zn})$ and copper $(\mathrm{Cu})$ blood concentrations in moderately exercised horses. Exercise changes a horse's physiology and metabolism, depending on its intensity and duration, and the animal training. The reactive oxygen species produced during physical activity could provoke oxidative damages to biomolecules (lipids, proteins, nucleic acids). The first enzymatic antioxidant of red-blood cells is cytosolic superoxide dismutase (SOD) which dismutes superoxide anion $\left(\mathrm{O}_{2}^{-}\right)$to hydrogen peroxide. SOD contains zinc $(\mathrm{Zn})$ and copper (Cu). Selenium (Se) and vitamin E hinder oxidative harm, but more research is needed to understand their antioxidant effect during exercise. We concluded that Se and vitamin E are powerful antioxidants, which did not affect erythrocyte SOD activity, and Zn and Cu blood concentrations; however, they were strongly modified by physical activity, results that would imply that moderate exercise also causes oxidative stress.
\end{abstract}

Keywords: Horses;Selenium; DL-alphatocopherol; Exercise; Superoxidedismutase; Zinc;Copper; Ascorbicacid; A-tocopherol; ß-carotene; Hydrogenperoxide; Erythrocyte; Osteogenesis; Pigmentation; Oxygen

\section{Introduction}

Exercise changes a horse's physiology and metabolism, depending on its intensity and duration, and the animal's capabilities and training, but changes due to moderate exercise have scarcely been studied in horses. Depending on the intensity, duration, and type of exercise, the reactive oxygen species produced could provoke oxidative stress [1]. Cytosolic superoxide dismutase (SOD) is the first enzymatic antioxidant of red-blood cells; it dismutes superoxide anion (02-) to hydrogen peroxide and it contains zinc $(\mathrm{Zn})$ and copper $(\mathrm{Cu})$. Selenium (Se) and vitamin E (E) hinder oxidative harm, but more research is needed to understand their antioxidant effect during exercise. The aim of this article is to briefly discuss the effect of selenium and vitamin E supplementation (synthetic vitamin E form) on the activity of erythrocyte superoxide dismutase and zinc (Zn) and copper $(\mathrm{Cu})$ blood concentrations in moderately exercised horses.

\section{Erythrocyte Superoxide Dismutase Activity}

SOD (EC 1.15.1.1) is necessary to maintain life in aerobic conditions [2]; two types of SOD have been identified in mammals: 1) Manganese-SOD (MnSOD) located mainly into the mitochondrial matrix; 2) CuZnSOD located mainly in the cytosol [3]. Each monomer of cytoplasmic SOD contains one atom of each
$\mathrm{Cu}$ and $\mathrm{Zn}$ [4]. SOD dismutes the superoxide anion to hydrogen peroxide and molecular oxygen [5]. In the absence of SOD, the superoxide anion can generate hydroxyl radicals, and trigger lipid peroxidation. Both, the diet and other environmental conditions influence the activity of CuZnSOD and MnSOD, enzymes that increase their activity under conditions that favor the production of superoxide radicals. It has been consigned, that Se and vitamin E supplementation affect physical performance [6]. However, physical activity increases the activity of the SOD $[6,7]$; this fact implies an increase in the production of superoxide anion. In jumping competitions performed in tropical conditions, where horses were not supplemented with antioxidants, it was observed that the activity of erythrocyte SOD increased 1.59 times $24 \mathrm{~h}$ after the event; this increase was explained in terms of the oxidants generated [8]. On the other hand, in elite cyclists it was observed that after two months of supplementation with vitamins E (400mg / day) and C (500mg / day), serum SOD activity decreased (from 14.60 to $13.24 \mathrm{U} / \mathrm{mg}$ protein) [9]. In another study in equines [10], the erythrocyte activity of SOD was not affected by physical exercise, when Se and vitamin E were applied. De Moffarts et al. [1] reported that in horses supplemented with Se, the use of the glutathione peroxidase system (main antioxidant enzyme of the erythrocyte) seems to be privileged with respect to SOD; in addition, erythrocyte has a 
superoxide anion pumping system that contributes to decrease anion concentrations [11].

\section{Zinc and Copper}

Zinc is a structural part of different enzymes, including mono-oxidases; it participates in osteogenesis and reproductive function, prevents chronic diseases as arteriosclerosis, diabetes and neurodegenerative disorders. It acts as an antioxidant and anti-inflammatory [12]; in addition, it reduces DNA damage [13]. Its deficiency causes stomatitis, parakeratosis, rough hair, joint stiffness, and reproductive disorders. In addition, an increase in lipoperoxidation markers is observed [14]. Zn performs its antioxidant function through proteins, such as metallothioneins; besides being a structural part of the SOD, in relation to copper [14]. Zn facilitates the neutralization of free radicals [15]. The dietary recommendations for the horse are $50 \mathrm{mg} / \mathrm{kg}$ DM [16]. Zn toxicity is rare, since it has a wide margin of safety in the horse [17]. Copper helps iron to be incorporated into hemoglobin; participates in osteogenesis, in pigmentation of the skin and iris, is an enzymatic cofactor (cytochrome oxidase C, tyrosinase, monoamine oxidase, ceruloplasmin, and galactosidase). $\mathrm{Cu}$ takes part of non-enzymatic proteins (erythrocuprein, hepatocuprein, brain cuprein, milk protein), besides it participates in gene expression.

The deficiency of $\mathrm{Cu}$ decreases the effectiveness of the immune system, causes anemia, fractures, achromotrichia, ataxia, spastic paralysis, severe incoordination, brain damage, alteration in the function of the respiratory chain. In humans, $\mathrm{Cu}$ has occasionally been associated with cardio-metabolic alterations, such as insulin resistance and diabetes, associated with obesity. Its main role as an antioxidant is its participation in the structure of SOD [18]. In the horse, dietary recommendations for $\mathrm{Cu}$ are $10 \mathrm{mg}$ / kg DM [16]; with significant tolerance to dietary copper, until $250 \mathrm{mg} / \mathrm{kg}$ of food [17]. The effect of physical activity on blood concentrations of $\mathrm{Zn}$ and $\mathrm{Cu}$ is controversial. Some authors do not report it [1] when antioxidants are supplemented (ascorbic acid, 11.5, a-tocopherol, 7.0, ß-carotene, 0.5, Cu, 0.187, Zn, 0.769, g / day; $7.0 \mathrm{mg} /$ day) in the diet. Other authors mention that blood $\mathrm{Zn}$ and $\mathrm{Cu}$ are not affected by race, gender, age or discipline [19]. In Anatolian horses an increase of $\mathrm{Cu}$ and $\mathrm{Zn}$ has been reported in animals that were not supplemented with Se and vitamin E [20]. We supplemented horses with both Se and vitamin E to studied erythrocyte SOD activity and $\mathrm{Cu}$ and $\mathrm{Zn}$ blood concentrations; our results just showed an effect of moderate exercise on the studied variables.

\section{Conclusion}

Selenium and vitamin E supplementation effect on erythrocyte SOD activity or $\mathrm{Zn}$ and $\mathrm{Cu}$ blood concentrations remains controversial. However, those variables are affected by moderate physical activity, results that could imply that moderate exercise also causes oxidative stress; in this case Se and vitamin E supplementation could benefit moderately exercised horses.

\section{References}

1. De Moffarts B, Kirschvink N, Art T, Pincemail J, Lekeux P (2005) Effect of oral antioxidantsupplementationonbloodantioxidantstatus in trainedthoroughbredhorses. Vet J 169: 65-74.

2. Michiels C, Raes M, Toussaint O, Remacle J (1994) Importance of Se-glutathioneperoxidase, catalase, and Cu/Zn-SOD forcellsurvivalagainstoxidative stress. Free RadicBiolMed 17(3): 235248.

3. ZidenbergCherr S, Keen CL, Lönnerdal B, Hurley LS (1983) Superoxidedismutaseactivity and lipidperoxidation in therat: developmentalcorrelationsaffectedbymanganesedeficiency. J Nut 113(12): 2498-2504.

4. Fridovich I (1976) Superoxidedismutases: studies of structure and mechanism. In Iron and CopperProteins. Springer, Boston, MA. pp. 530-539.

5. Juarez JC, Manuia M, Burnett ME, Betancourt O, Boivin B, et al. (2008) Superoxide dismutase 1 (SOD1) isessentialfor H202-mediated oxidation and inactivation of phosphatases in growth factor signaling. Proceedings of theNationalAcademy of Sciences, 105(20): 7147-7152.

6. Lamprecht ED, Williams CA (2012) Biomarkers of antioxidantstatus, inflammation, and cartilagemetabolism are affectedbyacute intense exercisebutnotsuperoxidedismutasesupplementation in horses. Oxid. Med. Cell. Longev 2012: 920932.

7. Akil M, Gurbuz U, Bicer M, Sivrikaya A, Mogulkoc R, et al. (2011) Effect of seleniumsupplementationonlipidperoxidation, antioxidantenzymes, and lactatelevels in ratsimmediately after acuteswimmingexercise. Biol Trace Elem Res 142(3): 651-659.

8. Soares JCM, Zanella R, Bondan C, Alves LP, de Lima MR, et al. (2011) Biochemical and antioxidantchanges in plasma, serum, and erythrocytes of horsesbefore and after a jumping competition. J EquineVetSci 31(7): 357-360.

9. Gupta C, Gupta PH, Singh B (2009) Effect of Vitamin Supplementation on Exercise Induced Oxidative Stress in Trained Elite Indian Cyclists. AJBIO 1: 166-70.

10. Ono $\mathrm{K}$, Inui $\mathrm{K}$, Hasegawa $\mathrm{T}$, Matsuki $\mathrm{N}$, Watanabe $\mathrm{H}$ et al. (1990) Thechanges of antioxidativeenzymeactivities in equineerythrocytesfollowingexercise. JJVS 52(4): 759-765.

11. Raftos JE., Whillier S, Kuchel PW (2010) Glutathionesynthesis and turnover in the human erythrocytealignment of a modelbasedondetailedenzymekineticswith experimental data. JBC 285(31): 23557-23567.

12. Prasad AS (2014) Zinc: anantioxidant and anti-inflammatoryagent: role of zinc in degenerativedisorders of aging. J Trace Elem MedBiol 28(4): 364-371.

13. Sharif R, Thomas P, Zalewski P, Fenech M (2015) Zinc supplementationinfluencesgenomicstabilitybiomarkers, antioxidantactivity, and zinc transporter genes in anelderlyAustralianpopulationwithlow zinc status. Mol NutFood Res 59(6): 1200-1212.

14. Bashandy SAEM, Omara EAA, Ebaid H, Amin MM, Soliman MS (2016) Role of zinc as anantioxidant and anti-inflammatoryto relieve cadmiumoxidative stress induced testicular damage in rats. AsianPac J TropBiomed 6(12): 1056-1064.

15. Cruz KJC, de Oliveira ARS, do Nascimento MarreiroD (2015) Antioxidant role of zinc in diabetes mellitus. WJD 6(2): 333-337.

16. MartinRosset W (2012)Nutrition et Alimentation des Chevaux. EditionsQuae.

17. NRC (2007)Nutrientsrequirements of horses, (6 $\left.6^{\text {th }} e d n\right)$,Natl Acad Press, Washington, DC, USA. 
18. Kamiya T, Takeuchi K, Fukudome S, Hara H, Adachi T (2018) Copperchaperone antioxidant-1, Atox-1, isinvolved in theinduction of SOD3 in THP-1 cells. BioMetals 31(1): 61-68.

19. Kirschvink N, De Moffarts B, Farnir F, Pincemail J, Lekeux $P$ (2006) Investigation of bloodoxidant/antioxidantmarkers in healthycompetitionhorses of differentbreeds. EquineVet J 38: 239-244.
20. Yur F, Dede S, Deger Y, Kilicalp D (2008) Effects of vitamin E and seleniumonserum trace and majorelements in horses. Biol Trace Elem Res 125(3): 223-228.

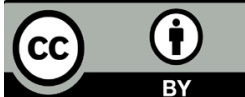

This work is licensed under Creative Commons Attribution 4.0 License DOI: 10.19080/JDVS.2018.07.555720
Your next submission with Juniper Publishers will reach you the below assets

- Quality Editorial service

- Swift Peer Review

- Reprints availability

- E-prints Service

- Manuscript Podcast for convenient understanding

- Global attainment for your research

- Manuscript accessibility in different formats

( Pdf, E-pub, Full Text, Audio)

- Unceasing customer service

Track the below URL for one-step submission https://juniperpublishers.com/online-submission.php 